\title{
EXPERIMENTALLY INDUCED HEAT- AND \\ COLD-SHOCK TOLERANCE IN ADULT Panstrongylus megistus (BURMEISTER) (HEMIPTERA, REDUVIIDAE)
}

\author{
GARCIA, S. L., ${ }^{1}$ GARCIA, N. L., ${ }^{2}$ OLIVEIRA, L. R., ${ }^{2}$ \\ RODRIGUES, V. L. C. C. ${ }^{3}$ and MELLO, M. L. S. ${ }^{1}$ \\ ${ }^{1}$ Departamentos de Biologia Celular e Parasitologia, Instituto de Biologia \\ ${ }^{2}$ Departamento de Estatística, Instituto de Matemática, Estatística e Computação Científica, Universidade Estadual \\ de Campinas (Unicamp), CEP 13084-971, Campinas, SP, Brazil \\ ${ }^{3}$ Sucen, CEP 13840-970, Mogi-Guaçu, SP, Brazil \\ Correspondence to: Maria Luiza Silveira Mello, Instituto de Biologia, Unicamp, Rua Zeferino Vaz, s/n, C.P. 6109, \\ CEP 13084-971, Campinas, SP, Brazil, e-mail: mlsmello@unicamp.br \\ Received February 22, 2002 - Accepted Juny 10, 2002 - Distributed August 31, 2003
}

(With 4 figures)

\begin{abstract}
The survival rate of domestic male and female adult Panstrongylus megistus was studied after sequential heat and cold shocks in order to investigate shock tolerance compared to that previously reported for nymphs. Sequential shocks were such that a milder shock $\left(0^{\circ} \mathrm{C}, 5^{\circ} \mathrm{C}, 35^{\circ} \mathrm{C}\right.$, or $40^{\circ} \mathrm{C}$ for $\left.1 \mathrm{~h}\right)$ preceded a severe one $\left(0^{\circ} \mathrm{C}\right.$ or $40^{\circ} \mathrm{C}$ for $12 \mathrm{~h}$ ), separated by intervals of $8,18,24$, and $72 \mathrm{~h}$ at $28^{\circ} \mathrm{C}$ (control temperature). The preliminary thermal shock induced tolerance to the more severe one, although tolerance intensity depended on the initial shock temperature and the interval between treatments. Despite the observed tolerance, the survival rate for insects subjected to both shocks decreased when compared to that of individuals subjected to a single mild shock. When tolerance differed with sex, females showed greater values than males. In contrast to the response detected in nymphs, for which higher heat tolerance values were sustained for intervals of up to $24 \mathrm{~h}$ (preliminary shock, $35^{\circ} \mathrm{C}$ ) or even longer (preliminary shock, $40^{\circ} \mathrm{C}$ ) between sequential shocks, significant values were verified in adults only for shock intervals of up to $8 \mathrm{~h}$ (preliminary shock, $40^{\circ} \mathrm{C}$ ). While findings for nymphs exhibited considerable cold-shock tolerance under conditions in which preliminary shocks were given at $5^{\circ} \mathrm{C}$ or $0^{\circ} \mathrm{C}$ and the periods between shocks were up to $72 \mathrm{~h}$ long, the adults were shown to be capable of acquiring a substancial tolerance response to a more severe cold shock only when the preliminary shock was given at $0^{\circ} \mathrm{C}$ and shock interval surpassed $18 \mathrm{~h}$. It is assumed that the mechanisms involved in the cellular protection of $P$. megistus under sequential temperature shocks (heat shock protein action?) may loose effectiveness with insect development.
\end{abstract}

Key words: Panstrongylus megistus, adults, heat shock, cold shock, survival, tolerance.

\section{RESUMO}

\section{Tolerância ao calor e ao frio experimentalmente induzida em alados de Panstrongylus megistus (Burmeister) (Hemíptera, Reduviidae)}

A taxa de sobrevivência de alados domiciliares machos e fêmeas de Panstrongylus megistus foi analisada, após choques seqüenciais quentes e frios, a fim de investigar aquisição de termotolerância em comparação a dados já reportados para ninfas. Os insetos foram submetidos a choques térmicos seqüenciais, sendo que um choque mais suave $\left(0^{\circ} \mathrm{C}, 5^{\circ} \mathrm{C}, 35^{\circ} \mathrm{C}\right.$ ou $40^{\circ} \mathrm{C}$ por $\left.1 \mathrm{~h}\right)$ precedeu o choque mais severo $\left(0^{\circ} \mathrm{C}\right.$ ou $40^{\circ} \mathrm{C}$ por $\left.12 \mathrm{~h}\right)$. Estes foram separados por intervalos de $8,18,24$ e $72 \mathrm{~h}$ a $28^{\circ} \mathrm{C}$ (temperatura-controle). Demonstrou-se que o choque térmico preliminar pode induzir tolerância ao mais severo, embora a intensidade de tolerância seja dependente da temperatura inicial do choque e do intervalo entre os tratamentos. Apesar da tolerância observada, a taxa de sobrevivência diminuiu 
em insetos submetidos a ambos os choques quando comparados àqueles espécimes submetidos a um único choque suave. Quando a tolerância diferiu com o sexo, as fêmeas apresentaram tolerância maior. Diferentemente da resposta observada em ninfas, para as quais a tolerância a choques quentes se estende até quando o período entre os choques é de $24 \mathrm{~h}$ (choque inicial a $35^{\circ} \mathrm{C}$ ) ou mais (choque inicial a $40^{\circ} \mathrm{C}$ ), taxa expressiva de tolerância nos adultos foi verificada apenas em condições de até $8 \mathrm{~h}$ de intervalo entre os choques, sendo o choque inicial dado a $40^{\circ} \mathrm{C}$. Também diferindo do que acontece às ninfas, cuja tolerância ao choque frio se expressa em todas as condições semelhantemente estudadas, nos adultos observou-se expressiva tolerância ao choque frio apenas quando o choque inicial foi dado a $0^{\circ} \mathrm{C}$ e o tempo entre choques seguidos ultrapassou $18 \mathrm{~h}$. Presume-se que em P. megistus os mecanismos que desempenham papel na proteção celular a choques seqüenciais de temperatura (proteínas de choque?) possam perder a eficácia com o desenvolvimento do inseto.

Palavras-chave: Panstrongylus megistus, adultos, choque quente, choque frio, sobrevivência, tolerância.

\section{INTRODUCTION}

According to the World Health Organization, Chagas' disease affects 20 million people, mostly in Central and South America. In Brazil, Chagas' disease is the third greatest cause of death by infectious parasitic diseases (Silveira \& Rezende, 1994; Dos Reis, 1997), with vectorial transmission being the principal route of infection. Studies of the responses of blood-sucking insects to various stress factors represent an important approach to understanding how to control these species (Rodrigues et al., 1991; Silva \& Silva, 1993; Garcia et al., 1999; Schmuñis, 2000).

Panstrongylus megistus (Burmeister), a bloodsucking hemipteran, is an important vector of Chagas' disease in Brazil because of its wide geographical distribution, high rates of infection, and its ability to adapt to artificial ecotopes (Forattini, 1980). P. megistus is native to Brazil and increasingly associated with human habitations because of the extensive destruction of its natural habitats (Silveira, 2000).

Following exposure to stress agents, changes in the survival rate, molting incidence, and nuclear phenotypes of $P$. megistus have been observed (Mello, 1978; Mello \& Raymundo, 1980; Garcia et al., 1999, 2000a, b). Similarly, heat and cold shock tolerance has been reported for $P$. megistus nymphs when they are subjected to sequential thermal shocks (Garcia et al., 2001a, b). However, cold-shock tolerance differed from heat-shock tolerance in nymphs of $P$. megistus. Heat-shock tolerance varied with the time between sequential shocks, thus being transiently controlled, whereas cold-shock tolerance did not change when intervals of 8-72 h between shocks were considered. In addition, sequential cold shocks produced a higher molting incidence when compared to sequential heat shocks (Garcia et al., 2001a, b).

Considering that differences in survival rates after single heat or cold shocks have been reported when adults are compared to nymphs and that thermal shock response in adults varies with sex (Garcia et al., 1999), the survival rate of $P$. megistus adults after sequential heat and cold shocks may also differ. In the present study, therefore, survival rates after sequential heat and cold shocks, in which a mild shock precedes a severe one, were investigated in male and female adults of $P$. megistus.

\section{MATERIAL AND METHODS}

Domestic adult male and female $P$. megistus specimens and reared in the laboratory at Sucen (Mogi-Guaçu, SP) of domestic habit were used. The insects were separated into groups of 50 specimens, each of which was put into glass cylinders (total: 21) which were then covered with cheesecloth and fastened with elastic bands. The insects were fasted for 15 days before being subjected to heat shock $\left(35^{\circ} \mathrm{C}\right.$ or $40^{\circ} \mathrm{C}$ for $\left.1 \mathrm{~h}\right)$ or cold shock $\left(5^{\circ} \mathrm{C}\right.$ or $0^{\circ} \mathrm{C}$ for $1 \mathrm{~h}$ ) followed by a return to their optimal rearing temperature $\left(28^{\circ} \mathrm{C}\right)$. After various intervals $(8 \mathrm{~h}$, $18 \mathrm{~h}, 24 \mathrm{~h}, 72 \mathrm{~h}$ ) following the mild shock, the insects were subjected to a more severe treatment $(12 \mathrm{~h}$ at $40^{\circ} \mathrm{C}$ or $0^{\circ} \mathrm{C}$ ).

The temperatures of $40^{\circ} \mathrm{C}$ and $0^{\circ} \mathrm{C}$ were chosen because of the need to use relatively extreme temperatures in comparison to those of the control $\left(28^{\circ} \mathrm{C}\right)$, the operational facilities, and for comparison 
with previous data on P. megistus (Garcia et al., 1999; 2001a, b). Based on previous results, temperatures of $35^{\circ} \mathrm{C}$ and $5^{\circ} \mathrm{C}$ were chosen as milder shock temperatures (Garcia et al., 2001a, b). A single shock at $40^{\circ} \mathrm{C}$ for $1 \mathrm{~h}$ has been reported to induce a less severe fall in the survival of adult specimens compared to that brought on by a single shock at $0^{\circ} \mathrm{C}$ for the same period (Garcia et al., 1999). Single shocks at $40^{\circ} \mathrm{C}$ and $0^{\circ} \mathrm{C}$ for $12 \mathrm{~h}$ are lethal to both male and female P. megistus adults (Garcia et al., 1999).

The choice of a moderate fasting condition prior to the shock assays was based on previous data which demonstrated a slightly better opportunity for survival of males, thus nourished and of domestic habit, under cold-shock conditions (Garcia et al., 1999). Immediately after the shock assays the insects were returned to the $28^{\circ} \mathrm{C}$ temperature, fed once a week on hen's blood, and monitored daily for 30 days to investigate survival rates changes.

Five control groups were used: 1 . insects maintained at $28^{\circ} \mathrm{C}$ but not subjected to heat or cold shock; 2 . insects subjected to a single cold shock at $0^{\circ} \mathrm{C}(1 \mathrm{~h}) ; 3$. insects subjected to a single cold shock at $5^{\circ} \mathrm{C}(1 \mathrm{~h}) ; 4$. insects subjected to a single heat shock at $35^{\circ} \mathrm{C}(1 \mathrm{~h})$; and 5 . insects subjected to a single heat shock at $40^{\circ} \mathrm{C}(1 \mathrm{~h})$.

The survival rates were compared using the Mantel-Hantzel non-parametric test, the Cox proportional hazard semi-parametric test, and a Weibull parametric test (Kalbfleish \& Prentice, 1980).

\section{RESULTS}

For consistency with previous papers (Garcia et al., $2001 \mathrm{a}, \mathrm{b}$ ), only results obtained with MantelHantzel non-parametric test are presented, although all three statistical tests gave similar results.

\section{Total sample (1050 specimens)}

There was strong evidence of a difference among treatments when all the subgroups $(\mathrm{W}=69.1$, $\mathrm{p}=0.000)$ and both sexes $(\mathrm{W}=9.6, \mathrm{p}=0.002)$ were considered.

\section{Control samples of each subgroup (250 specimens)}

When control groups 1 to 5 were compared among themselves, there was strong evidence of a difference in survival ( $\mathrm{W}=14.4, \mathrm{p}=0.006)$. However, there was no difference for $\operatorname{sex}(\mathrm{W}=1.2, \mathrm{p}=0.280$ ).

Insect survival in each control group was $70 \%$ for $1 \mathrm{~h}$ at $0^{\circ} \mathrm{C} ; 68 \%$ for $1 \mathrm{~h}$ at $5^{\circ} \mathrm{C} ; 96 \%$ for $1 \mathrm{~h}$ at $35^{\circ} \mathrm{C}$; $76 \%$ for $1 \mathrm{~h}$ at $40^{\circ} \mathrm{C}$; and $80 \%$ for unshocked insects. Each shock (heat or cold, short or long) decreased insect survival (Figs. 1.2, 2.2, 3.2, and 4.2). The groups in which most insects survived were those which received no shock or which were subjected to a shock at $35^{\circ} \mathrm{C}$, followed by those which received shocks at $40^{\circ} \mathrm{C}, 0^{\circ} \mathrm{C}$, and $5^{\circ} \mathrm{C}$.

\section{Insects subjected to a single heat $\left(35^{\circ} \mathrm{C}\right.$ and $\left.40^{\circ} \mathrm{C}\right)$ or cold $\left(0^{\circ} \mathrm{C}\right.$ and $\left.5^{\circ} \mathrm{C}\right)$ shock}

Insects subjected to a single shock at $35^{\circ} \mathrm{C}$ (group 4) showed results that differed significantly from the ones of those subjected to a single shock at $40^{\circ} \mathrm{C}$ (group 5) $(\mathrm{W}=394.8, \mathrm{p}=0.000)$. A similar result was obtained with a cold shock at $0^{\circ} \mathrm{C}$ (group 2) compared with that at $5^{\circ} \mathrm{C}$ (group 3$)(\mathrm{W}=$ $307.5, \mathrm{p}=0.000$ ). There was also a difference when the survival of insects subjected to single heat shocks (groups 4 and 5) was compared with that of insects subjected to single cold shocks (groups 2 and 3).

The survival for males plus females subjected to sequential heat shocks was $37 \%$, whereas the survival for those subjected to cold shocks was $67 \%$. However, when comparing control groups that received single heat shocks $(4+5)$ with control groups that received single cold shocks $(2+3)$, the survival rate was greater for heat-shocked insects (86\%; cold-shocked insects, $69 \%$ ).

\section{Insects subjected to an initial shock at $0^{\circ} \mathrm{C}$ for $1 \mathrm{~h}$}

Since the survival curves obtained after all the treatments differed significantly at $p \leq 0.05$, multiple comparisons were necessary to identify the different curves. To guarantee an overall significance level of 0.05 , a p value of 0.01 was used for subsequent tests which compared the curves.

There was significant difference when a single shock at $0^{\circ} \mathrm{C}$ (group 2) was compared with sequential shocks at this temperature $(\mathrm{W}=248.2$, $\mathrm{p}=0.000$ ). The insects subjected to sequential cold shocks at $0^{\circ} \mathrm{C}$ differed significantly from each other ( $\mathrm{W}=15.9, \mathrm{p}=0.001)$. When the shocks were separated by intervals of 18,24 , or $72 \mathrm{~h}$ at $28^{\circ} \mathrm{C}$, these insects survived longer than those subjected to shocks separated by an 8 -h interval. The survival rates of insects subjected to sequential cold shocks with intervals of $18 \mathrm{~h}$ and $24 \mathrm{~h}$ at $28^{\circ} \mathrm{C}$ between shocks were similar to each other $(\mathrm{W}=0.8, \mathrm{p}=$ $0.359)$. The survival curve of insects whose interval between shocks was $72 \mathrm{~h}$ and that of insects subjected to a single shock at $0^{\circ} \mathrm{C}$ were similar (Fig. 
$1.2 ; \mathrm{W}=0.7, \mathrm{p}=0.397)$. Survival was not affected by sex ( $\mathrm{W}=2.8, \mathrm{p}=0.092$; Fig. 1.1 ). The relative frequency of survival confirmed the difference between control group 2 and that of the insects subjected to two shocks.

\section{Insects subjected to an initial shock at $5^{\circ} \mathrm{C}$ for $1 \mathrm{~h}$}

Although the survival rate of insects subjected to cold shock $18 \mathrm{~h}$ after the first shock was apparently higher than of the remaining groups, including control group 3 , the difference was not statistically consistent $(\mathrm{W}=7.8, \mathrm{p}=0.100$; Fig. 2.2).

Comparison of control group 3 with insects subjected to sequential shocks showed that the female survival rate was greater than that of males $(\mathrm{W}=$ $7.8, p=0.005$; Fig. 2.1)
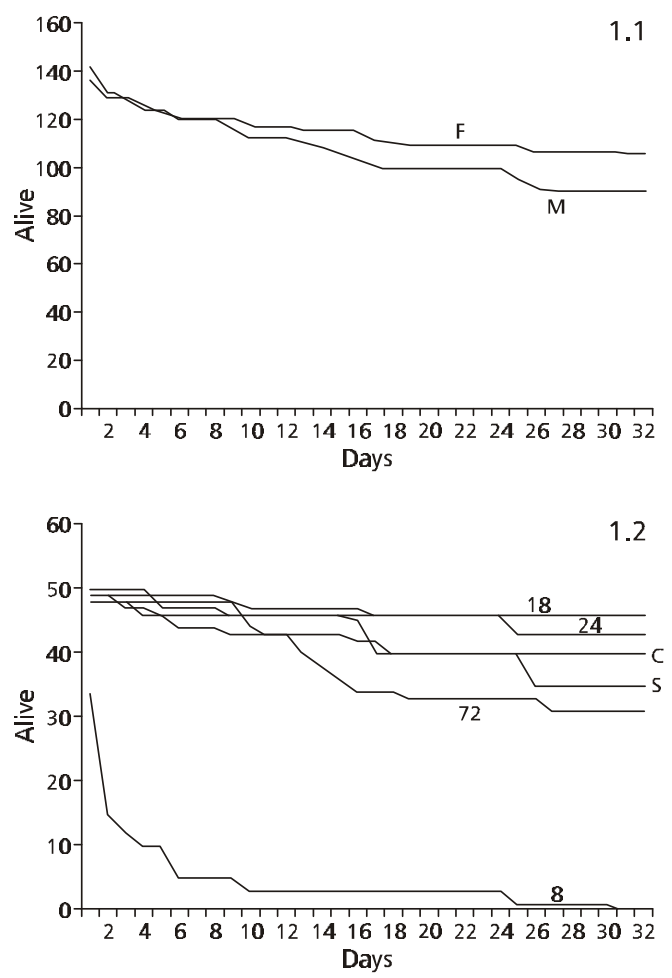

Insects subjected to an initial shock at $35^{\circ} \mathrm{Cfor} 1 \mathrm{~h}$

There was a significant difference between survival of control group 4 and that of insects subjected to sequential shocks separated by various periods at $28^{\circ} \mathrm{C}(\mathrm{W}=55.2, \mathrm{p}=0.000)$, with control group 4 surviving longer than insects subjected to sequential shocks. There was no difference among insects subjected to sequential shocks separated by $8,18,24$, and $72 \mathrm{~h}$ at $28^{\circ} \mathrm{C}(\mathrm{W}=1.0, \mathrm{p}=0.801$; Fig. 3.2), although females always survived longer than males (Fig. 3.1).

\section{Insects subjected to an initial shock at $40^{\circ} \mathrm{C}$ for $1 \mathrm{~h}$}

There was strong evidence of a difference in the survival rate of control group 5 compared to that of insects subjected to sequential heat shocks ( $\mathrm{W}=$ $164.8, \mathrm{p}=0.000)$.
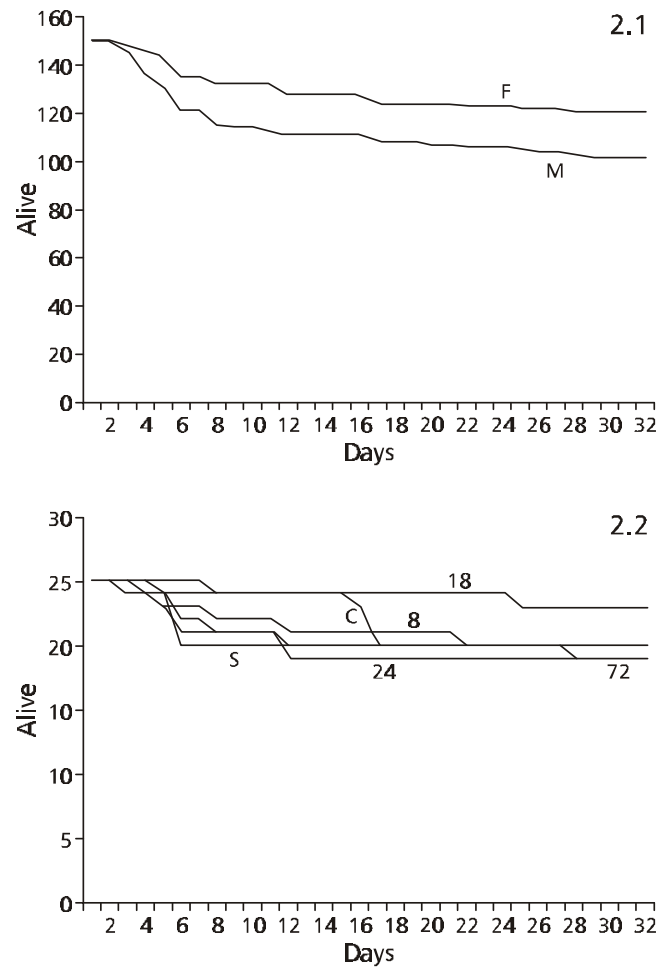

Figs. 1.1-2.2 - Survival curves for cold-shocked adult $P$. megistus. Fig. 1.1 - A single shock at $0^{\circ} \mathrm{C}(1 \mathrm{~h})$ in males $(\mathrm{M})$ and females (F). Fig. 1.2 - Sequential shocks at $0^{\circ} \mathrm{C}$ (first one for $1 \mathrm{~h}$; second one for $12 \mathrm{~h}$ ) separated by different periods at $28^{\circ} \mathrm{C}$. Controls: $28^{\circ} \mathrm{C}(\mathrm{C})$ and a single shock at $0^{\circ} \mathrm{C}$ for $1 \mathrm{~h}(\mathrm{~S})$. Fig. $2.1-$ A single shock at $5^{\circ} \mathrm{C}(1 \mathrm{~h})$ in males $(\mathrm{M})$ and females $(\mathrm{F})$. Fig. 2.2 - Shock at $5^{\circ} \mathrm{C}(1 \mathrm{~h})$ followed by a shock at $0^{\circ} \mathrm{C}(12 \mathrm{~h})$, separated by different periods at $28^{\circ} \mathrm{C}$. Controls: $28^{\circ} \mathrm{C}(\mathrm{C})$ and a single shock at $5^{\circ} \mathrm{C}$ for $1 \mathrm{~h}(\mathrm{~S})$. 
Only the results for insects subjected to a second shock $8 \mathrm{~h}$ after the first were similar to those of the control $(\mathrm{W}=2.6, \mathrm{p}=0.105)$. These two conditions produced a survival rate greater than the remaining treatments (control, $76 \% ; 8 \mathrm{~h}, 60 \% ; 18$ h, 2\%; 24 h, 6\%; 72 h, 8\%) (Fig. 4.2). The survival rate of insects subjected to a second shock after an interval of 24 and $72 \mathrm{~h}$ at $28^{\circ} \mathrm{C}$ was similar in both groups $(\mathrm{W}=1.3, \mathrm{p}=0.247)$. Although there was a significant difference among all groups subjected to sequential heat shocks, the results were not affected by sex ( $\mathrm{W}=0.0, \mathrm{p}=0.993$; Fig. 4.1).

\section{Control group at $28^{\circ} \mathrm{C}$}

There was no difference in the survival rates of males and females in control group $1(\mathrm{~W}=0.0, \mathrm{p}=$
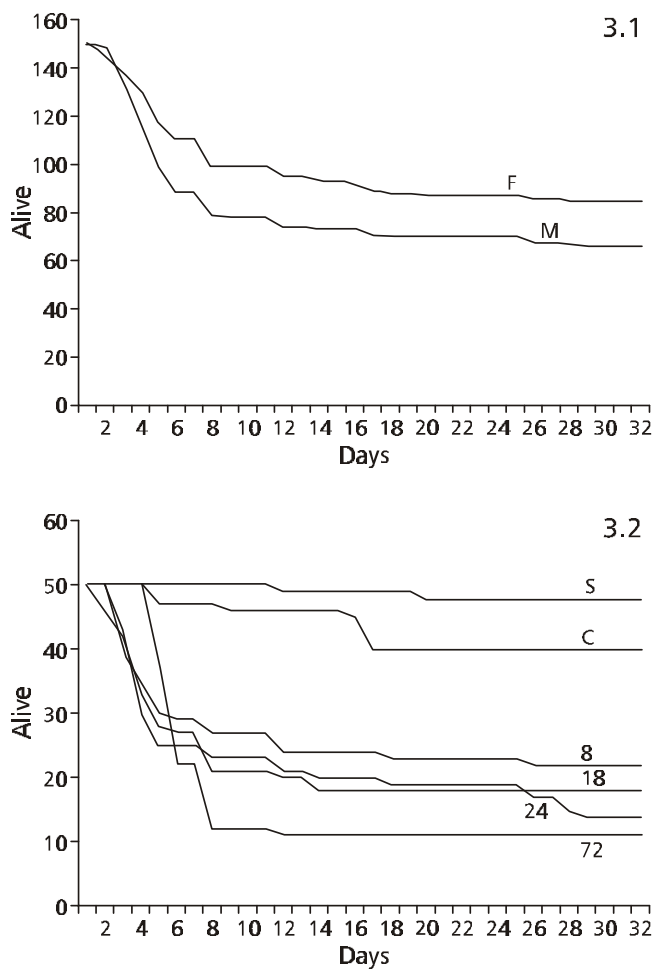

0.954). Comparison of the groups that received one or two shocks with group 1 showed that the insects in group 2 survived for lesser periods than those in group 1 whereas insects of almost all groups subjected to sequential cold shocks had survival curves similar to that of control group 1 (Fig. 1.2). The insects in group 3 and all samples subjected to sequential cold shocks had survival curves similar to that of control group 1. However, control 3 insects survived less than insects belonging to control 1 (Fig. 2.2). Control group 4 insects survived more than control group 1 insects, although the survival curves of both were similar (Fig. 3.2). Control group 5 and insects subjected to heat sequential shocks in which the shocks were separated by 18,24 , and $72 \mathrm{~h}$ at $28^{\circ} \mathrm{C}$, survived less than control group 1 insects (Fig. 4.2).
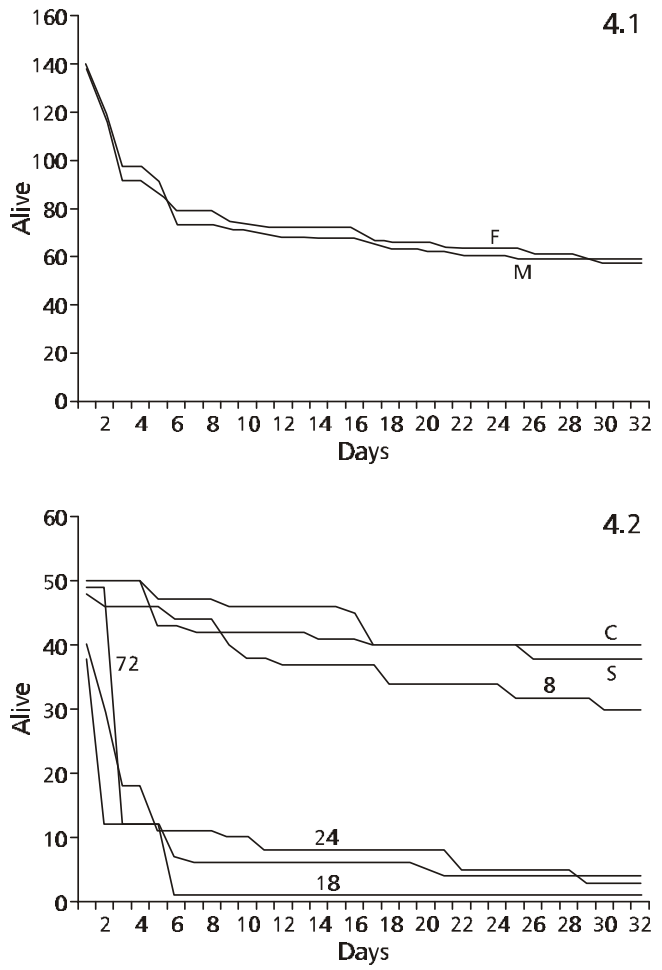

Figs. 3.1-4.2 - Survival curves for heat-shocked adult P. megistus. Fig. 3.1 - A single shock at $35^{\circ} \mathrm{C}(1 \mathrm{~h})$ in males $(\mathrm{M})$ and females $(\mathrm{F})$. Fig. 3.2 - Preliminary shock at $35^{\circ} \mathrm{C}(1 \mathrm{~h})$ followed by a shock at $40^{\circ} \mathrm{C}(12 \mathrm{~h})$, separated by different periods at $28^{\circ} \mathrm{C}$. Controls: $28^{\circ} \mathrm{C}(\mathrm{C})$ and a single shock at $35^{\circ} \mathrm{C}$ for $1 \mathrm{~h}(\mathrm{~S})$. Fig. 4.1 - A single shock at $40^{\circ} \mathrm{C}(1 \mathrm{~h})$ in males (M) and females (F). Fig. 4.2 - Sequential shocks at $40^{\circ} \mathrm{C}$ (first one for $1 \mathrm{~h}$; second one for $12 \mathrm{~h}$ ) separated by different periods at $28^{\circ} \mathrm{C}$. Controls: $28^{\circ} \mathrm{C}(\mathrm{C})$ and a single shock at $40^{\circ} \mathrm{C}$ for $1 \mathrm{~h}(\mathrm{~S})$. 


\section{DISCUSSION}

Overall results indicated induced tolerance to heat and cold shocks in adults of P. megistus in terms of their survival of sequential shocks in which a mild shock preceded a more severe one. Shocks at $40^{\circ} \mathrm{C}$ or $0^{\circ} \mathrm{C}$ for $12 \mathrm{~h}$ are both lethal to these insects when given isolatedly (Garcia et al., 1999). The tolerance rate was found to be predominantly a function of the temperature of the preliminary shock and time elapsed between sequential shocks. The different responses to sequential thermal shocks probably elicit different cellular protection mechanisms against stress.

Significant values of heat-shock tolerance were elicited in adults only when they were subjected to sequential treatments in which the preliminary shock was given at $40^{\circ} \mathrm{C}$ and the second one $8 \mathrm{~h}$ after the first shock, results which differ from findings reported for nymphs (Garcia et al., 2001b). In the case of nymphs, higher values of heat-shock tolerance were sustained for intervals between shocks extending up to $24 \mathrm{~h}$ (preliminary shock, $35^{\circ} \mathrm{C}$ ) or even longer (preliminary shock, $40^{\circ} \mathrm{C}$ ) (Garcia et al., 2001b).

The mechanism(s) involved in heat-shock tolerance in adults probably requires(e) that the shock being given must drastically shift from $28^{\circ} \mathrm{C}$ to $40^{\circ} \mathrm{C}$ in order to elicit efficient protective action. This is possibly necessary to activate significant changes in genomic expression, with specialized metabolic responses thus being triggered (Gasch et al., 2000). Even so, this result is very transient, unlike that reported for nymphs (Garcia et al., 2001b).

The cold-shock tolerance response in adults of P. megistus also differed from the response described for nymphs of the same species under identical experimental conditions (Garcia et al., 2001a). P. megistus nymphs exhibit expressive coldshock tolerance under various sequential shock conditions (preliminary shock at $5^{\circ} \mathrm{C}$ or $0^{\circ} \mathrm{C}$; periods at $28^{\circ} \mathrm{C}$ extending from 8 to $72 \mathrm{~h}$ long between shocks) (Garcia et al., 2001a). In the present study, adults were found to acquire substancial tolerance to a severe cold shock at $0^{\circ} \mathrm{C}$ for $12 \mathrm{~h}$ but only when this shock was preceded by a mild shock at $0^{\circ} \mathrm{C}$ for $1 \mathrm{~h}$ and the time between shocks surpassed $18 \mathrm{~h}$. Maybe in this case, because of protective mechanisms being elicited effectively, adults require a longer period than do nymphs. Even so, tolerance in adults was much lower than that elicited in nymphs. The $5^{\circ} \mathrm{C}$ temperature was not found to be a good elicitor of protective mechanisms in adults, a finding completely different from that verified for nymphs subjected to the same experimental conditions (Garcia et al., 2001a).

It was concluded that the mechanisms involved in cellular protection against sequential temperature shocks in P. megistus may lose effectiveness with insect development. A certain disadvantage was also found for males in the adult phase.

Acquisition of heat-shock tolerance is attributed to involvement in a wide sense with heatshock proteins (HSP) (Welch, 1993). These may also be involved with cold-shock tolerance in some insects (Denlinger et al., 1991). A preliminary immunocytochemical investigation of HSP70 in Malpighian tubules of $P$. megistus subjected to heat shock at $40^{\circ} \mathrm{C}$ for $1 \mathrm{~h}$ failed to identify an increase in this protein type (Garcia, 2002), nor did another study on Malpighian tubules of Drosophila (Singh \& Lakhotia, 1995). In the latter case, it was assumed that a rapid fall in concentration of HSP70 as mediated by proteolytic action might affect the immunocytochemical results and so does not mean absence of this protein (Singh \& Lakhotia, 1995). Additional investigation on HSP is thus required on P. megistus subjected to thermal shocks.

In any case, although not discarding a differential participation of HSP types in the heat- and cold-shock tolerance responses of $P$. megistus, other mechanisms should also be considered, among which are modulation of DNA topoisomerase activity, and even expression of stress genes unrelated to the heatshock response as well as genetic variation in metabolic traits (Clark \& Fucito, 1998; Lopes-Garcia $\&$ Forterre, 2000).

The different patterns of heat- and cold-shock tolerance of $P$. megistus as a function of its different developmental phases may have favored this species' adaptation to different environments, especially when considering its nymphal phases, and could explain its increase and wide distribution throughout Brazil. Considering the marked susceptibility of $P$. megistus to Trypanosoma cruzi, present results may be relevant to our understanding of the biological responses to stress in these insects in either their natural environment or the laboratory. 
Acknowledgments - This work was partially supported by the State of São Paulo Research Foundation (Fapesp, grant nos. 98/0826-4 and 99/2547-8) and the Brazilian National Research \& Development Council (CNPq). The authors are indebted to Mr. Pedro Ribeiro da Silva for his technical support.

\section{REFERENCES}

CLARK, A. G. \& FUCITO, C. D., 1998, Stress tolerance and metabolic response to stress in Drosophila melanogaster. Heredity, 81: 514-527.

DENLINGER, D. L., JOPLIN, K.H., CHEN, C. P. \& LEE Jr., R. E., 1991, Cold shock and heat shock, pp. 131-148. In: R. E. Lee \& D. L. Denlinger, Insects at low temperature. Chapman and Hall, New York/London.

DOS REIS, G. A., 1997, Cell-mediated immunity in experimental Trypanosoma cruzi infection. Parasitol. Today, 13: 335-342.

FORATTINI, O. P., 1980, Biogeografia, origem e distribuição da domiciliação de triatomíneos no Brasil. Rev. Saúde Públ., 14: 256-299.

GARCIA, S. L., 2002, Investigação imunocitoquímica de HSP 70 em túbulos de Malpighi de Panstrongylus megistus submetidos a choques de temperatura. Report, 5 - FAPESP (Ref. 98/0826-4).

GARCIA, S. L., RODRIGUES, V. L. C. C., GARCIA, N. L., FERRAZ-FILHO, A. N. \& MELLO, M. L. S., 1999, Survival and molting incidence after heat and cold shocks in Panstrongylus megistus Burmeister. Mem. Inst. Oswaldo Cruz, 94: 131-137.

GARCIA, S. L., MELLO, M. L. S., RODRIGUES, V. L. C. C. \& GARCIA, N. L., 2000a, Nuclear phenotype changes after heat shock in Panstrongylus megistus (Burmeister). Mem. Inst. Oswaldo Cruz, 95: 271-277.

GARCIA, S. L., MELLO, M. L. S., GARCIA, N. L. \& RODRIGUES, V. L. C. C., 2000b, Changes in nuclear phenotypes following cold shock in Panstrongylus megistus (Burmeister). Mem. Inst. Oswaldo Cruz, 95: 893-898.

GARCIA, S. L., GARCIA, N. L., RODRIGUES, V. L. C. C. $\&$ MELLO, M. L. S., 2001a, Effect of sequential cold shocks on survival and molting incidence in Panstrongylus megistus (Burmeister) (Hemiptera, Reduviidae). Cryobiology, 41: 74-77.

GARCIA, S. L., MELlO, M. L. S., GARCIA, N. L. \& RODRIGUES, V. L. C. C., 2001b, Experimentally induced heat-shock tolerance in Panstrongylus megistus (Burmeister) (Hemiptera, Reduviidae). J. Med. Entomol., 38: 510-513.
GASCH, A. P., SPELLMAN, P. T., KAO, C. M., CARMELHAREL, O., EISEN, M. B., STORZ, G., BOTSTEIN, D. \& BROWN, P. O., 2000, Genomic expression programs in the response of yeast cells to environmental changes. Mol. Biol. Cell, 11: 4241-4257.

KALBFLEISH, J. D. \& PRENTICE, R. L., 1980, The statistical analysis of failure time data. John Wiley \& Sons, New York.

LOPEZ-GARCIA, P. \& FORTERRE, P., 2000, DNA topology and thermal stress response, a tale from mesophiles and hyperthermophiles. Bioessays, 22: 738-746.

MELLO, M. L. S., 1978, Mechanism of polyploidization in the Malpighian tubes of a blood-sucking reduviid hemipteran. Rev. Bras. Genet., 1: 97-102.

MELLO, M. L. S. \& RAYMUNDO, H. H., 1980, Nuclear fusion in the Malpighian tubes of a blood-sucking hemipteran. Cytologia, 45: 203-209.

RODRIGUES, V. L. C. C., MELLO, M. L. S., FERRAZ-FILHO, A. N. \& DANTAS, M. M., 1991, Sobrevivência e ocorrência de muda em Triatoma infestans Klug (Hemiptera, Reduviidae) após choque de temperatura. Rev. Saúde Públ., 25: 461-467.

SCHMUÑIS, G. A., 2000, A tripanosomíase americana e seu impacto na saúde pública das Américas, pp. 1-12. In: Z. Brener, Z. A. Andrade \& M. Barral-Netto, Trypanosoma cruzi e Doença de Chagas. Guanabara Koogan, Rio de Janeiro.

SILVA, I. G. \& SILVA, H. H. G., 1993, Influência da temperatura na biologia de triatomíneos. III. Panstrongylus megistus (Burmeister, 1835) (Hemiptera, Reduviidae). Rev. Bras. Entomol., 37: 489-496.

SILVEIRA, A. C. \& REZENDE, D. F., 1994, Epidemiologia e controle da transmissão vetorial da doença de Chagas no Brasil. Rev. Soc. Bras. Med. Trop., 27: 11-12.

SILVEIRA, A., 2000, Profilaxia, pp. 75-86. In: Z. Brener, Z. A. Andrade \& M. Barral-Netto, Trypanosoma cruzi e Doença de Chagas. Guanabara Koogan, Rio de Janeiro.

SINGH, B. N. \& LAKHOTIA, S. C., 1995, The non-induction of HSP70 in heat-shocked Malpighian tubules of Drosophila larvae is not due to constitutive presence of HSP70 or HSC70. Curr. Sci., 69: 178-182.

WELCH, W. J., 1993, How cells respond to stress. Sci. Amer, 5: $56-64$. 